University of Nebraska - Lincoln

DigitalCommons@University of Nebraska - Lincoln

\title{
Territoriality, Prospecting, and Dispersal in Cooperatively Breeding Micronesian Kingfishers (Todiramphus cinnamominus reichenbachii)
}

Dylan C. Kesler

U.S. Geological Survey, dkesler@vt.edu

Susan M. Haig

U.S. Geological Survey, Susan_Haig@usgs.gov

Follow this and additional works at: https://digitalcommons.unl.edu/usgsstaffpub

Kesler, Dylan C. and Haig, Susan M., "Territoriality, Prospecting, and Dispersal in Cooperatively Breeding Micronesian Kingfishers (Todiramphus cinnamominus reichenbachii)" (2007). USGS Staff -- Published Research. 664.

https://digitalcommons.unl.edu/usgsstaffpub/664

This Article is brought to you for free and open access by the US Geological Survey at DigitalCommons@University of Nebraska - Lincoln. It has been accepted for inclusion in USGS Staff -- Published Research by an authorized administrator of DigitalCommons@University of Nebraska - Lincoln. 
The Auk 124(2):381-395, 2007

(c) The American Ornithologists' Union, 2007.

Printed in USA.

This article is a U.S. government work, and is not subject to copyright in the United States.

\title{
TERRITORIALITY, PROSPECTING, AND DISPERSAL IN COOPERATIVELY BREEDING MICRONESIAN KINGFISHERS (TODIRAMPHUS CINNAMOMINUS REICHENBACHII)
}

\author{
Dylan C. Kesler ${ }^{1,2,3}$ and Susan M. Haig ${ }^{1}$ \\ ${ }^{1}$ U.S. Geological Survey Forest and Rangeland Ecosystem Science Center, 3200 SW Jefferson Way, \\ Corvallis, Oregon 97331, USA; and \\ ${ }^{2}$ Department of Fisheries and Wildlife, Oregon State University, Corvallis, Oregon 97331, USA
}

Aвstract. - We investigated territoriality, prospecting, and dispersal behavior in cooperatively breeding Pohnpei Micronesian Kingfishers (Todiramphus cinnamominus reichenbachii) throughout the annual cycle using radiotelemetry and color-band resights. Mean home-range size was 6.3 ha and territories were 8.1 ha. Within territories, Micronesian Kingfishers shared $63 \%$ of their home-range space with coterritorial occupants, and 3\% was shared with extraterritorial conspecifics. Birds on cooperative territories had larger home ranges that overlapped more with coterritory occupants' home ranges than birds in pair-held territories. Despite evidence suggesting that resources necessary for survival and reproduction occurred on each territory, Micronesian Kingfishers of all age and sex classes made extraterritorial prospecting movements. Prospecting was rare; it comprised only $4.3 \%$ of our observations. When birds departed on forays, they were gone for $\sim 1.9 \mathrm{~h}$ and returned to home territories before sunset. Prospecting by dominant birds was temporally correlated with courtship and nest initiation, and birds were observed at neighboring nest sites with opposite-sex conspecifics during the period when females were available for fertilization. Juveniles and helpers prospected throughout the year and made repeated homesteading movements to dispersal destinations before dispersing. Mean dispersal distance for radiomarked individuals was $849 \mathrm{~m}$. Results suggest that prospecting in Micronesian Kingfishers is a complex behavior that provides information for dispersal decisions and familiarity with dispersal destinations. Additionally, extraterritorial movements may provide covert opportunities for reproduction, which have potential to profoundly influence the distribution of fitness among helper and dominant Micronesian Kingfishers. Received 29 August 2005, accepted 14 March 2006.

Key words: Caroline Islands, dispersal, foray, Halcyon cinnamomina, homesteading, Micronesia, prospecting, Todiramphus cinnamominus.

\section{Territorialité, prospection et dispersion chez des Todiramphus cinnamominus reichenbachii présentant une reproduction coopérative}

Résumé.-Au cours du cycle annuel, nous avons étudié la territorialité, la prospection et le comportement de dispersion chez des Martins-chasseurs cannelle (Todiramphus cinnamominus reichenbachii) coopérant pour la reproduction. Pour ce faire, la télémétrie et la ré-observation d'oiseaux marqués de bagues colorées ont été utilisés. Le domaine vital moyen s'étendait sur 6,3 ha et les territoires, sur 8,1 ha. Les martins-chasseurs partageaient $63 \%$ de leur domaine vital avec les autres occupants du territoire et $3 \%$ avec leurs congénères extraterritoriaux. Les oiseaux occupant des

\footnotetext{
${ }^{3}$ Present address: Biological Sciences, 4095 Derring Hall, Virginia Tech, Blacksburg, Virginia 24060, USA.

E-mail: dkesler@vt.edu
} 
territoires en coopération avaient des domaines vitaux plus grands qui chevauchaient davantage celui des autres occupants du territoire que les couples d'oiseaux occupant seuls le territoire. Malgré des signes évidents suggérant la présence des ressources nécessaires à la survie et la reproduction dans chaque territoire, les martins-chasseurs des deux sexes et de toutes les classes d'âge ont effectué des déplacements extraterritoriaux de prospection. La prospection était rare, comptant seulement pour $4,3 \%$ de nos observations. Lorsque les oiseaux partaient pour une incursion, ils s'absentaient pendant ?1,9 h et revenaient dans leurs territoires avant le coucher du soleil. La prospection par les oiseaux dominants était corrélée dans le temps avec la parade nuptiale et l'initiation des nids. Ces oiseaux étaient observés à des sites de nidification voisins en compagnie de congénères du sexe opposé pendant la période où les femelles pouvaient être fertilisées. Les juvéniles et les aides au nid prospectaient tout au long de l'année. Ils ont effectué des déplacements répétés vers des destinations de dispersion avant la dispersion elle-même. La distance moyenne de dispersion chez les individus munis d'émetteurs était de 849 $\mathrm{m}$. Les résultats suggèrent que la prospection chez les Martins-chasseurs cannelle est un comportement complexe qui les informe dans leur décisions de dispersion et leur permet de se familiariser avec les destinations de dispersion. De plus, les mouvements extraterritoriaux peuvent fournir des opportunités clandestines pour la reproduction, lesquelles ont le potentiel d'influencer profondément la distribution $\mathrm{du}$ fitness parmi les martins-chasseurs dominants et les aides au nid.

KNOWLEDGe of Dispersal and space use is essential for testing hypotheses about the evolution of sociality in cooperatively breeding species. Predominant theories about cooperative breeding suggest that there are fitness benefits associated with delayed dispersal ("benefits of philopatry" hypothesis; Stacey and Ligon 1991), including the potential to inherit resources when natal or nearby territory vacancies occur. The cost of delaying can be outweighed if the inherited resources provide enhanced fitness when compared with those in outlying areas (Komdeur 1991, 1992, 1994). Timing of dispersal is variable among species, however, and little is known about the proximate factors influencing when and how dispersal occurs.

In many cooperatively breeding species, some individuals disperse as juveniles, whereas others delay for extended periods (Koenig and Pitelka 1981, Brown 1987, Stacey and Koenig 1990, Walters et al. 1992, Ligon 1999, Ekman et al. 2004). This pattern implies that each individual gathers information about resource quality, territory occupancy, and breeding vacancies in nearby areas before making dispersal decisions. Some have proposed that birds obtain information pertinent to dispersal through social interactions along territorial boundaries (Hale et al. 2003) and by making extraterritorial prospecting movements into the surrounding landscape (Bowen et al. 1989, Reed et al. 1999, Koenig et al. 2000, Fedy and Stutchbury 2004). However critical this information is to understanding sociality in cooperative breeders, prospecting movements are rare and elusive, and attempts at empirical assessments can be beset by methodological biases (Koenig et al. 1992, 2000; Walters 2000; Clobert et al. 2001; Johnson and Horvitz 2005). Thus, few have identified how prospecting relates to dispersal, where prospecting birds travel, and what information birds acquire while prospecting, despite the paramount importance of these data to understanding proximate dispersal decisions in cooperative breeders (Walters 2000; but see Doolan and Macdonald 1996, Schjørring et al. 1999, Fedy and Stutchbury 2004).

Once delayed dispersal has arisen, the behavior can be maintained by extrinsic limitations in resources necessary for reproduction ("ecological constraints" hypothesis; Emlen 1982). Habitats suitable for survival and nesting of cooperative species are often saturated with territories that are packed boundary-to-boundary and aggressively defended, which suggests that territory availability may function as the limited resource that prevents young from dispersing ("habitat saturation" hypothesis; 
Selander 1964, Brown 1974, Gaston 1978, Stacey 1979, Koenig and Pitelka 1981). In pair-breeding species, investigators have identified spatially and temporally variable factors that influence the distribution of individuals, including environmental conditions, intraspecific interactions (Brown 1964, Emlen and Oring 1977, Hixon 1980, Schoener 1983, Lima 1984, Stamps and Krishnan 1999), and resource dispersion and predictability (Brown 1964, Emlen and Oring 1977, Bollmann et al. 1997, Clark and Shutler 1999, Zwicker and Walters 1999, Tyre et al. 2001). Yet few have investigated proximate mechanisms underlying space use and territoriality in cooperative species (Langen and Vehrencamp 1998, Breininger and Oddy 2004, Fedy and Stutchbury 2004).

Within a territory, each individual bird uses space, which makes up its home range (White and Garrott 1990), and together the home ranges for a pair or social group comprise a territory. Space within territories is aggressively defended from conspecifics along territory boundaries (Brown 1964). There is a lack of information about how space is partitioned among individuals, and the actual extent to which spatial resources are distributed among a cooperatively breeding group has never been assessed, to our knowledge. Although birds within a territory are generally believed to share resources, some space may also be reserved for specific social classes, and relationships may differ among cooperative and pair-held territories.

We investigated territoriality, prospecting movements, and dispersal behaviors in cooperatively breeding Pohnpei Micronesian Kingfishers (Todiramphus cinnamominus reichenbachii). We synthesized observations of colorbanded and radiomarked birds to assess the distribution and movement of individuals within and among territories. We evaluated home ranges, territories, prospecting distances, timing, and the relationship between dispersal and extraterritorial movements using a global information system (GIS) and behavior observations. Additionally, radiotelemetry and color-band observations were used to assess within- and among-year dispersal. Results from the present study are intended to lend insight into space use and dispersal and provide information for recovery efforts for the Guam Micronesian Kingfisher (T. c. cinnamominus). The Guam Micronesian Kingfisher was listed as endangered under the U.S. Endangered Species Act following precipitous declines caused by introduced brown tree snakes (Boiga irregularis; U.S. Fish and Wildlife Service 1984, Savidge 1987). They now exist only as a captive population in U.S. zoos (Haig and Ballou 1995, Haig et al. 1995, Bahner et al. 1998, Kesler and Haig 2004). Plans have been announced for reintroducing the species back into its last native habitats on Guam, but this cannot be done without information about spatial distribution and dispersal (U.S. Fish and Wildlife Service 2004).

\section{Methods}

Research was conducted on the island of Pohnpei, Federated States of Micronesia $\left(6^{\circ} 52^{\prime} \mathrm{N}, 158^{\circ} 13^{\prime} \mathrm{E}\right)$. Pohnpei is a circular island $\sim 20 \mathrm{~km}$ in diameter and it has the highest peak in the Micronesian chain ( $800 \mathrm{~m}$; Engbring et al. 1990). Extensive lowland coastal plateau and mangrove swamps surround the inner mountain range, which is characterized by dense tropical rainforests. Three sites were selected for this investigation: the Ranch $\left(6^{\circ} 57^{\prime} \mathrm{N}, 158^{\circ} 12^{\prime} \mathrm{E}\right)$, College of Micronesia $\left(6^{\circ} 54^{\prime} \mathrm{N}, 158^{\circ} 9^{\prime} \mathrm{E}\right)$, and Palikir study areas $\left(6^{\circ} 55^{\prime} \mathrm{N}, 158^{\circ} 9^{\prime} \mathrm{E}\right)$. Each site included strand vegetation, early-succession and mature lowland rainforest, grassland, urban vegetation, and agroforest. Grassland included pastures and fallow fields. Early-succession rainforest and agroforest vegetation were characterized by lower canopy (2-20 m high) hibiscus (Hibiscus tiliaceus), banana (Musa sapientum), coconut (Cocos nucifera), breadfruit (Artocarpus altilis), and sakau (Piper methysticum). Mature forests had higher canopies (25-30 m high) and were dominated by mango (Mangifera indica), dohng (Campnosperma brevipetiolata), sadak (Elaeocarpus carolinensis), karara (Myristica insularis), ais (Parinari laurina), and tree ferns (Cyathea spp.; see Mueller-Dombois and Fosberg 1998, Buden 2000).

Study population. - We follow the terminology of recent literature (e.g., Haydock and Koenig 2002) by using "dominant" to refer to the putative breeders on a territory and "helper" for offspring that have delayed dispersal through subsequent parental reproductive attempts. Additionally, we use "juvenile" to describe progeny from the most recent breeding season. We radiomarked and color-banded a population of Micronesian Kingfishers on study areas between 
January 1999 and November 2004. The study populations were intensively observed from January to July 1999, March to September 2000, September 2001, September 2002 to January 2003, October and November 2003, and September 2004. Birds were radiomarked during 1999, 2000, and 2002, and color-banded every year. Because observers were present on study areas daily, we believe that the social classes (dominant, helper, juvenile) of all individuals were known. Birds were captured in mist nets and fitted with a 1.8-g telemetry package (Holohil Systems, Ottawa, Canada) using the leg-harness design (Rappole and Tipton 1991) and a unique combination of colored leg bands. We observed no negative effects from capture, observation, color bands, or radiomarking. Age and sex of each bird was determined using molecular analyses and plumage characteristics (D. C. Kesler et al. unpubl. data). In Pohnpei, adult Micronesian Kingfishers older than one year have white breast plumage (Pratt et al. 1987, Fry and Fry 1992), whereas fledglings and juveniles have varying degrees of rufous breast plumage. The rufous feathers progressively molt into white along the ventral feather tract (D. C. Kesler et al. unpubl. data). The plumage of helpers occasionally shows remnant rufous coloration, but plumage of older helpers is similar to that of dominants (D. C. Kesler pers. obs.).

Radiotelemetry and home range.-We used radiotelemetry and GIS analyses to evaluate territoriality and movement in Micronesian Kingfishers. Hand-held Yagi antennas, compasses, and global positioning systems (GPS; March III, Corvallis Microtechnologies, Corvallis, Oregon) were used to record bearing groups of two to five $($ mean $=2.98)$ directional bearings for each Micronesian Kingfisher $(n=$ 2,108 locations). If birds were visually observed during telemetry sessions, we recorded their actual location using the offset function of the GPS ( $n=1,942$ locations). Bearing groups were used to estimate the best maximum-likelihood locations for each bird using default settings in LOAS (Ecological Software Solutions, Urnäsch, Switzerland; see Acknowledgments), and they were excluded if LOAS failed to identify a location or if observers noted that birds moved during the observation period. Locations with 95\% error ellipses (White and Garrott $1990)>5,000 \mathrm{~m}^{2}(\sim 10 \%$ of the area of a mean Micronesian Kingfisher home range) were also excluded $(n=17)$. Most birds were located once daily, and all observations were separated by $\geq 2 \mathrm{~h}$ to avoid autocorrelation (mean temporal separation of subsequent observations $=27$ h). Additionally, kernel density analyses can be biased by clusters of locations during the breeding season (White and Garrott 1990), so we eliminated 104 locations that were within $15 \mathrm{~m}$ of nest sites. The process yielded 3,929 locations.

Differential detection probabilities and missing data have the potential to bias representations of movement and resource use (Porter and Dooley 1993; Koenig et al. 1996, 2000). For example, data are biased when observers fail to identify the presence or location of color-banded or radiomarked animals that have moved off study areas or into portions of the landscape that hinder detection. We avoided biasing results by locating birds every time we attempted to find them, with the exception of several attempts cut short by factors unrelated to bird movement, such as weather and equipment failures. Several study-specific factors allowed us to consistently locate birds, including presampling identification of biasing factors, the 1- to 2-km detection distance of the Holohil transmitters in the generally flat landscape, and the short-distance movements of Micronesian Kingfishers. When birds were not immediately identified on their home territory, observers traversed the surrounding landscape until the location of prospecting individuals was identified. Radiotelemetry results can also be biased if diurnal movement patterns correlate with telemetry sampling regimes. Thus, we repeatedly sampled throughout the day and night. We focused most sampling on daylight hours, because observer comments and 60 sequential telemetry locations recorded during nighttime hours indicated that birds do not move substantially between sunset and sunrise. Additionally, we balanced sampling equally during each 2-h time block between 0600 and 1800 hours (approximate sunrise and sunset at $7^{\circ} \mathrm{N}$ latitude; observation [mean \pm SD] per time block $=649 \pm 69$ ). During telemetry observation periods, behaviors were also recorded if the observers could visually identify individuals. Particular emphasis was placed on recording aggressive interactions, fights, and courtship behaviors, and noting behavior during prospecting movements. We believe this method yielded a data set that was temporally 
and spatially representative of Micronesian Kingfisher space use and movement throughout the annual cycle.

Prospecting, dispersal, and behavior.-We employed a combination of empirical and subjective criteria to identify telemetry locations recorded while birds were prospecting. First, we used the ARCVIEW animal movement extension (Hooge and Eichenlaub 1997) to conduct kernel density analyses (White and Garrott 1990) of telemetry locations. Home range was considered to be the $95 \%$ use contour of each bird within a particular year (White and Garrott 1990, Roshier and Reid 2003). The 95\% use contours for dominants on each territory were then amalgamated to delineate the boundaries of 16 focal study territories (see Kesler and Haig 2005b). Kernel polygons were considered to be outliers and excluded from the territory amalgamations if they were distinctly separated from the main territory polygon and surrounded only a single telemetry point. Extraterritorial movements were then defined as locations of birds outside territorial boundaries by $>50 \mathrm{~m}$, a figure selected because it represents approximately half the radius of a mean-sized circular home range. Radiomarked birds were considered to have dispersed if they remained at a prospecting destination for $>24 \mathrm{~h}$ and after daily movements to home territories ceased. We considered that color-banded individuals dispersed if they moved from one territory to another between years.

Analysis.-Statistical analyses were conducted using SAS, version 8e (SAS Institute, Cary, North Carolina). Two-sample $t$-tests were used to make comparisons between sexes, and the linear-model analysis of variance (ANOVA; Proc GLM) function of SAS ANALYST was used to evaluate social class comparisons. Chi-square analyses were calculated by hand. Statistical tests used for each analysis, adjustment methods for multiple comparisons, 95\% confidence intervals $(95 \% \mathrm{CI})$, and least-squared mean parameter estimates are presented whenever appropriate. Unless otherwise noted, estimates are reported as means $\pm S D$, and differences are considered statistically significant at $\alpha<0.05$.

\section{Results}

From 1999 to 2004, 57 male and 53 female Micronesian Kingfishers were marked with individual-specific color-band combinations. On 16 focal territories, 43 birds were marked as dominants, 12 as helpers, and 39 as juveniles or nestlings. Fifty-seven were observed during only the year they were marked, 22 were observed during two field seasons, 13 were observed for three seasons, one bird was observed during a fifth, and one during a sixth season. During the 1999, 2000, and 2002 breeding seasons, 54 Micronesian Kingfishers were radiomarked and tracked for 16 weeks each (Tables 1 and 2). Additionally, one female and two males were radiomarked during consecutive years, yielding a total of 57 kingfisher*radio years.

Space distribution within and among territories. Home ranges were evaluated for radiomarked Micronesian Kingfishers (Table 1). The mean error ellipse for bearing groups was $409 \mathrm{~m}^{2}$, and a mean of $64 \pm 22$ locations (minimum 13, maximum 100) were used for each home-range estimate. Mean home-range size was $7.31 \pm 6.83$ ha

TABLE 1. Estimates of home-range size and prospecting distances from home territories for each sex and social class of Micronesian Kingfishers during 1999, 2000, and 2002, using radiotelemetry and kernel-density analyses. Estimates (mean \pm SD) are presented for each class.

\begin{tabular}{|c|c|c|c|c|c|c|c|}
\hline \multirow[b]{2}{*}{ Sex } & \multirow[b]{2}{*}{ Class } & \multicolumn{3}{|c|}{ All observations } & \multicolumn{3}{|c|}{ Prospecting } \\
\hline & & Birds $^{a}$ & $\begin{array}{c}\text { Mean } \\
\text { observations }\end{array}$ & $\begin{array}{l}\text { Home-range } \\
\text { size (ha) }{ }^{b}\end{array}$ & Birds & $\begin{array}{l}\text { Observa- } \\
\text { tions (\%) }\end{array}$ & $\begin{array}{c}\text { Mean } \\
\text { distance }\end{array}$ \\
\hline $\mathrm{F}$ & Dominant & 16 & $69 \pm 20$ & $5.7 \pm 2.7$ & 6 & 0.7 & 77 \\
\hline $\mathrm{F}$ & Helper & 3 & $63 \pm 23$ & $7.8 \pm 4.8$ & 2 & 9.0 & 399 \\
\hline $\mathrm{F}$ & Juvenile & 9 & $56 \pm 13$ & $5.2 \pm 3.7$ & 8 & 9.4 & 221 \\
\hline $\mathrm{M}$ & Dominant & 16 & $67 \pm 18$ & $7.1 \pm 2.7$ & 9 & 1.2 & 114 \\
\hline $\mathrm{M}$ & Helper & 7 & $60 \pm 33$ & $7.9 \pm 4.4$ & 6 & 11.0 & 429 \\
\hline M & Juvenile & 6 & $51 \pm 27$ & $4.6 \pm 3.4$ & 1 & 2.8 & 189 \\
\hline
\end{tabular}

a Sample sizes are presented in bird*years.

${ }^{\mathrm{b}}$ Data for three dispersing individuals are addressed elsewhere, because they exerted undue leverage on estimates. 
TABLE 2. Home-range overlap within and among Micronesian Kingfisher territories on Pohnpei during 1999, 2000, and 2002. Results are presented as area (ha), with sample sizes in parentheses. $P$-values are reported for two-sample $t$-tests for equal means.

\begin{tabular}{lccc}
\hline \hline & \multicolumn{3}{c}{ Overlapping home range area } \\
\cline { 2 - 4 } Overlap type & Neighbors & Within territories & $P$-value \\
\hline Dominant-dominant & $0.14(22)$ & $4.39(8)$ & $<0.0001$ \\
Dominant-helper & $0.34(12)$ & $4.78(10)$ & $<0.0001$ \\
Dominant-fledgling & $0.11(21)$ & $3.29(9)$ & $<0.0001$ \\
Fledgling-helper & $0.04(2)$ & $4.74(3)$ & 0.017 \\
Helper-helper ${ }^{a}$ & $1.18(6)$ & - & - \\
Fledgling-fledgling & $0.01(20)$ & $2.05(4)$ & $<0.0001$ \\
\hline
\end{tabular}

${ }^{a}$ Home ranges of neighboring helpers overlapped significantly more than home ranges of all other neighboring social classes.

for all radiomarked birds. The disparate point distributions of three individuals that dispersed during observations yielded estimates that exerted undue leverage on results, so they were excluded and are treated below. After disperser data were removed, mean home-range size was $6.28 \pm 3.33$ ha (Table 1$)$.

There was suggestive evidence that homerange sizes differed among social classes (ANOVA, $P=0.09$ ). Juvenile home ranges were the smallest and helper home ranges were the largest, but pairwise comparisons were insignificant (Scheffe's adjustment for multiple comparisons, $P>0.05$, 95\% CI: -0.36 to 6.23 ha; Table 1). Similarly, there was no difference in the home-range size of males and females ( $t$-test; $P=$ 0.26 ). The relationship between sociality and home-range size was evaluated by comparing home ranges of birds in cooperative group-held territories $(n=31)$ with those on pair-held territories $(n=26)$. Overall, the home ranges of birds on pair-held territories were 1.8 ha smaller than those on cooperative territories ( $t$-test, $P=0.04$, 95\% CI: 0.1-3.5 ha). By social class, dominant home ranges were 2.4 ha larger $(P=0.009 ; 95 \%$ CI: $0.7-4.0 \mathrm{ha})$, and the home ranges of fledglings were 1.8 ha larger $(P=0.04 ; 95 \%$ CI: $0.1-3.5$ ha) on cooperative territories.

Groups or pairs of Micronesian Kingfishers share space within each territory. However, aggressive interactions among coterritorial occupants suggest that not all space is commonly used by every individual, and that portions of each territory may be reserved for use by only specific birds. To gain insight into the sharing of space within territories, we assessed the amount of space used simultaneously by radiomarked birds, or the amount of homerange overlap (Table 2). Forty-two birds were radiomarked while a coterritorial occupant was simultaneously tracked, and dyad combinations of these individuals yielded 34 pairs of simultaneous coterritorial home ranges. Home ranges of coterritorial birds overlapped by a mean of $3.97 \pm 2.10$ ha. No differences were identified between the area overlapped by two dominants, dominants and helpers, dominants and juveniles, helpers and juveniles, or two juveniles (one-way ANOVA, $F=1.78, \mathrm{df}=4$ and $33, P=0.16$; Table 2). In regard to mean homerange size, results illustrate that birds share $63 \%$ of their home range with other individuals on the same territory, but that not all space is commonly used by all territory occupants. When a comparison was made between mean homerange overlap on cooperative (mean $\pm \mathrm{SE}, 2.75 \pm$ 0.39 ha, $n=12)$ and pair-held territories $(4.63 \pm$ 0.46 ha, $n=22)$, results indicated that home ranges on cooperative territories overlapped by 1.88 ha more than those on less-crowded pairheld territories (two-sample $t$-test, $P=0.01,95 \%$ CI: 0.48-3.29 ha).

Micronesian Kingfisher occupancy on 16 focal territories was recorded between 1999 and 2003. Territories were defended (in territory ${ }^{*}$ years) by single individuals $(n=2)$, breeding pairs $(n=13)$, a single dominant and a juvenile $(n=1)$, breeding pairs and juveniles $(n=25)$, and cooperative family groups $(n=24)$. Dominant mortalities altered group membership in 4 territory*years, and social composition could not be determined for 11 territory*years. When home ranges of radiomarked dominants were amalgamated to empirically define each territory, the mean 
territory size was 8.1 ha. There was no difference in the size of territories that hosted cooperative groups during at least one field season $(n=12)$, and consistently pair-held territories $(n=4)(F=$ 2.41, $\mathrm{df}=1$ and $14, P=0.14$ ).

When conspecifics were encountered within territories or along territory boundaries, the birds were excluded through aggressive interactions. Chases and bill-swooping displays were observed 99 times during the course of fieldwork. Among the aggressive displays observed on the study areas, 29 were located near territorial boundaries delineated by telemetry, and 13 were inside territories. All age and sex classes participated in the behaviors, which usually terminated when one or more territory occupants chased intruders from confrontation areas. We evaluated the effects of spatial exclusion by assessing home-range overlap among 83 dyad pairs of radiomarked birds on neighboring territories. The home ranges of neighboring birds overlapped less than those of birds on the same territory ( 0.21 vs. 3.97 ha; two-sample t-test, $P<0.001$ ), a pattern that applied to all combinations of social classes (Table 2). The home ranges of the six neighboring pairs of helpers overlapped more than other combinations of neighboring dominants, helpers, or juveniles (ANOVA, $F=12.96$, df $=5$ and $77, P<$ $0.0001)$, which indicates that helpers invaded the space of extraterritorial conspecifics more than other social classes.

Prospecting movements.-Prospecting was observed in 31 individuals of all age and sex classes (Table 1). Of 3,929 telemetry locations recorded during our investigation, 170 were observed during 152 prospecting movements (multiple locations were recorded during long forays). Observer remarks about behavior accompanied 113 of the prospecting movements, and the GIS verified that all locations were $>50 \mathrm{~m}$ from home-territory boundaries. All prospecting movements terminated with birds returning to home territories before sunset. We used two methods to evaluate mean departure time, mean foray duration, and mean return time. On 59 occasions, we observed birds on their home territories and prospecting during the same day. We estimated a mean departure time of 1025 hours (1.7 SE, $n=27$ ) and a mean return time of 1221 hours (2.4 SE, $n=27$ ) by averaging the times birds were observed on their home territories with the times they were observed prospecting. The difference in means yields an estimated foray duration of 1.9 h ( $t$-test, $P=0.0012,95 \%$ CI: $0.7-3.1)$. We also observed round-trips on four occasions, when birds were detected on their home territory, while prospecting, and then back on their home territory again on the same day. The mean estimated departure time, prospecting duration, and return time for round trips were similar to those identified above (0935 hours, $3.0 \mathrm{~h}$, and 1237 hours, respectively).

Prospecting frequency differed among social classes (ANOVA, arcsine-square-roottransformed proportion observations prospecting, $F=4.32, \mathrm{df}=2$ and $61, P=0.018$ ), with prospecting comprising $2.4 \%$ more of the helper telemetry observations than those of the dominants (Bonferroni correction and back-transformed, $P=0.03$, 95\% CI: 0.01-8.5\%). Similarly, helpers prospected $161 \mathrm{~m}$ farther from home territory boundaries than dominants (ANOVA, $F=4.95, \mathrm{df}=2$ and 29, $P=0.014,95 \%$ CI: 31-292 m). No differences were identified between juveniles and dominants or juveniles and helpers $(P>0.05)$. Sexes did not differ $(t$-test, $P>0.05)$, and no difference was identified among cooperative and pair-held territories ( $t$-test of arcsine-square-root-transformed proportion observations prospecting, $P>0.05$; mixed-models ANOVA, $P>0.05)$. Although restricted samples prevent analysis of sex by social-class interactions, the pattern of prospecting frequencies suggests similarity between juvenile and dominant males and between juvenile and helper females.

We evaluated the temporal distribution of prospecting by comparing the number of observed monthly prospecting movements with the number expected if they were proportional to all telemetry observations. Prospecting movements were temporally disproportionate to predictions for all three social classes (dominants: $\chi^{2}=16, \mathrm{df}=2, P<0.001$; helpers: $\chi^{2}=54, \mathrm{df}=7$, $P<0.001$; juveniles: $\chi^{2}=21$, $\mathrm{df}=4, P<0.001$; cells with predicted occurrence $<5$ were excluded). Additionally, the monthly proportion of prospecting observations differed among dominants, helpers, and juveniles (Kruskal-Wallis test, $\chi^{2}=$ 6.86 , df $=2, P=0.029)$. The timing of dominant prospecting corresponded with reproduction, because the proportion that occurred during breeding months (April-August) differed from that during nonbreeding months ( $t$-test, $F=$ 10.2 , df $=1$ and $9, P=0.01$; estimated $2.3 \%$ more 


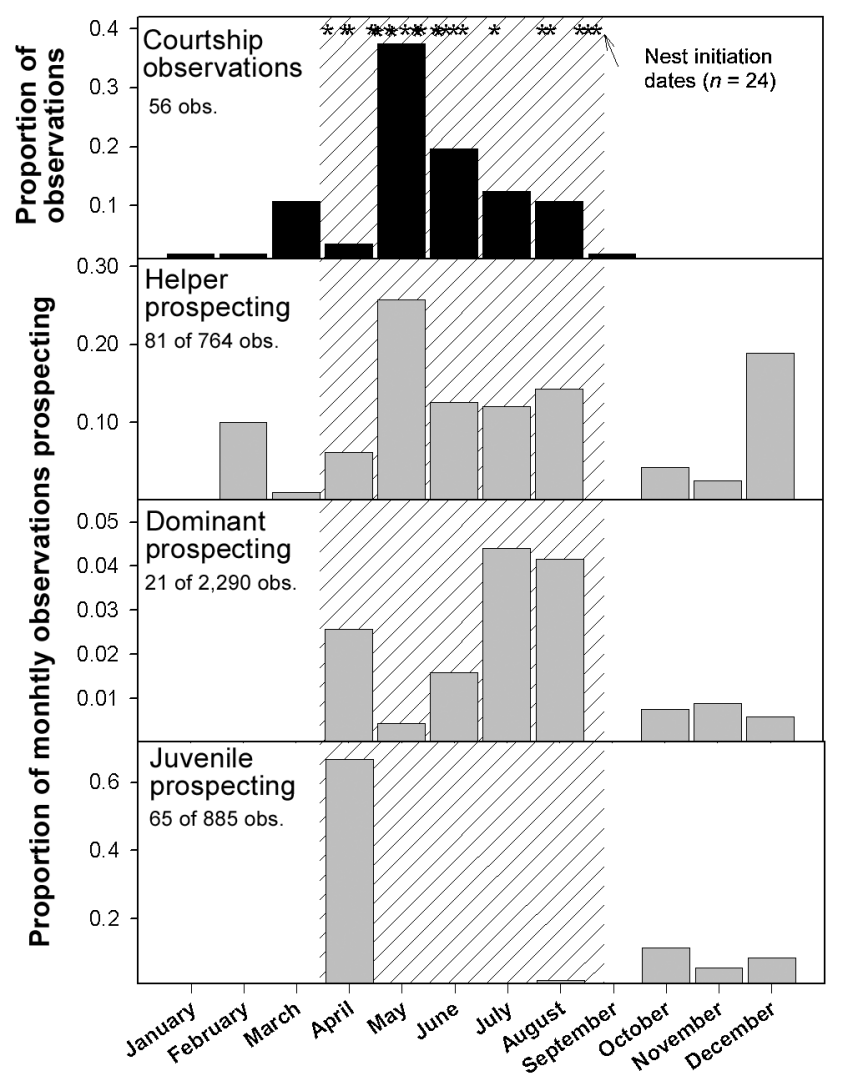

Fig. 1. Temporal distribution of observed courtship behaviors and prospecting movements among social classes of Pohnpei Micronesian Kingfishers. Crosshatching denotes period of nest initiations on focal territories between 1999 and 2004. Courtship observations included copulations, courtship feedings, and nest excavations ( $n=7,6$, and 43, respectively) between 1999 and 2004. Histograms illustrate the monthly proportion of courtship behaviors among all behaviors, and monthly proportion of extraterritorial observations, for radiomarked Micronesian Kingfishers in each social class during 1999, 2000, and 2001.

prospecting observations during the breeding season, 95\% CI: $0.7-3.9 \%$; Fig. 1). Although the histogram in Figure 1 appears to illustrate a similar pattern between courtship behavior and prospecting in helpers, mean monthly prospecting movements did not differ significantly between the breeding and nonbreeding months for helpers or juveniles ( $t$-test, $P>0.05$ for both).

Behavioral observations support assertions that extraterritorial movements may be motivated by birds' search for extrapair mating opportunities. Courtship behaviors were observed in association with eight forays. Male helpers were observed at the nests of neighboring birds three times, and telemetry showed that the neighboring female was present on at least one of those occasions while her mate was elsewhere. Furthermore, estimates based on hatch dates for the nests visited by prospecting males $(n=3)$ indicated that visits occurred within three days of respective laying dates, when females were presumably available for fertilization. The visited females then went on to nest with their mates on home territories. Courtship calling with nonmates was observed during four extraterritorial movements. Aggressive territorial head-dipping displays, aerial pursuit chases, and territory calling also characterized prospecting observations $(n=2,5$, and 9 , respectively). 
Philopatry and dispersal.-Five birds colorbanded as juveniles (one male, four females) and five banded as helpers (four males, one female) were observed on natal territories during subsequent years. However, none remained to obtain new mates and breed on natal areas, which suggests that territory inheritance by helpers or offspring is rare or does not occur in Micronesian Kingfishers. Three males and five females dispersed from natal territories during our investigation. Two (one male, one female) dispersed as juveniles, four (one male, three females) remained as helpers for one breeding season before dispersal, and two (one male, one female) were not observed between fledging and filling a vacancy on neighboring territories two years later. Three birds dispersed while being radiotracked (one male: 1,023 m; two females: 849 and $716 \mathrm{~m}$ ), and the remaining five color-banded birds dispersed between field seasons (two males: 419 and 1,372 m; three females: 295,419 , and $171 \mathrm{~m}$ ). No differences were found between mean dispersal distances of radiomarked and color-banded birds ( $t$-test, $P=0.31$, $n=8$ ), nor between males and females ( $t$-test, $P=0.14, n=8)$. Dispersal had been previously evaluated in terms of the number of territories between natal areas and breeding locations, and our observations show a 2.05 territory-width separation between natal and breeding territories in radiomarked Micronesian Kingfishers (assuming a diameter of $320 \mathrm{~m}$ from circular territory with mean territory area). Before dispersal, three radiomarked individuals made repeated prospecting visits $($ mean $=13)$ to the locations where they eventually dispersed. The fate of 31 color-banded juveniles and 10 helpers that disappeared from study areas remains unknown, but many of these individuals probably dispersed to surrounding areas where they were not subsequently resighted.

Insight into territory ownership and inheritance comes from the behavior of territoryholding dominants following death of their mates. Territory ownership is not reserved for either sex. A dominant male was left as the single territory holder when a hunter shot his radiomarked mate, and he remained on the territory with the previous year's offspring. On two other territories, dominant females retained ownership after the deaths of radiomarked mates. One of these females was observed courtship-calling with an unmarked male 17 days after her mate died, and the other bred with a new mate the following year. Inferences about territory ownership can also be drawn from changes in territory occupancy across years. New mates on two territories replaced dominant males, whereas the dominant females remained across breeding seasons. On six territories, dominant males remained, whereas female mates were replaced.

\section{Discussion}

Pohnpei Micronesian Kingfishers hold allpurpose territories throughout the year. Their high degree of territoriality was illustrated by results showing that the home ranges of coterritorial occupants overlapped by $63 \%$, whereas the home ranges of birds on neighboring territories overlapped by only 3\%. Brown (1964) suggested that territoriality would evolve if resources were distributed so that an individual could satisfy its nesting requirements, food supply, and attraction of a mate in a relatively fixed area, and if individuals could balance the costs of defensive aggression with the benefits of defended resources. Accordingly, Micronesian Kingfishers are terrestrial generalists that primarily subsist on the abundant invertebrate and lizard prey items (orders Isoptera, Lepidoptera, and Othoptera; Emoia spp; Family Gekkonidae; D. C. Kesler unpubl. data). Birds nest in arboreal termitaria that are apparently not limited in abundance (Kesler 2002, Kesler and Haig 2005b), and they do not require specialized cover resources in the amiable climactic conditions on Pohnpei (Kesler and Haig 2005a). Additionally, $<1 \%$ of our telemetry locations from dominant kingfishers were extraterritorial, which further suggests that Pohnpei Micronesian Kingfisher territories contained all the resources necessary for survival and reproduction.

On cooperative territories, home ranges of dominants were larger than those on pairheld territories. Resource availability has been shown to cause sociality in Seychelles Warblers (Acrocephalus sechellensis; Komdeur 1991, 1992, 1994) and Red-cockaded Woodpeckers (Picoides borealis; Walters et al. 1992), and larger territories and greater resources have been correlated with sociality in other cooperative species, such as Splendid Fairy-wren (Malurus splendens; Brooker and Rowley 1995). Greater or higherquality resources on natal areas can also influence reproductive success (Forbes et al. 2002, 
Luck 2003, Lõhmus and Väli 2004) and breeding behavior (Emlen and Oring 1977, Walters et al. 1992, Byrkjedal et al. 1997, Pribil and Searcy 2001), which may induce potential dispersers to delay. Thus, additional insight into restrictions placed on potential dispersers by resource availability on the landscape, as well as the relative resource benefits that might be obtained on natal areas by delaying, would be gained from additional study of the interaction between specific foraging and nesting resources, reproductive success, and cooperative breeding in Micronesian Kingfishers.

Prospecting. - Juvenile and helper Micronesian Kingfishers may prospect to gather information about potential dispersal destinations. In the cooperatively breeding Red-cockaded Woodpecker, there is evidence that reduced familiarity with the environment decreases disperser fitness (Pasinelli et al. 2004). Previous investigations have also shown that knowledge of localized resources can affect foraging efficiency, territoriality, predator detection, and mate attraction (Greenwood 1980, Greenwood and Harvey 1982, Pärt 1994, Smith and Metcalfe 1997, Bensch et al. 1998). For Micronesian Kingfishers, nesting and foraging resources are vital to daily survival and reproduction, and experiences during prospecting may educate birds about the relative availability of these resources on natal areas and in the surrounding landscape. We observed birds foraging, excavating nest cavities, and in proximity to the nests of neighbors while prospecting. A similar nest-resource-assessment behavior has been observed in other cooperative species (e.g., Green Woodhoopoes [Phoeniculus purpureus]; Ligon and Ligon 1990) and in many pair-breeding species (see Reed et al. 1999). While prospecting, Micronesian Kingfishers may have also been assessing the ability of conspecifics to defend territories through direct interactions like territorial head-dipping displays, aerial pursuit chases, and territory calling, or through indirect indicators like plumage (e.g., Fan-tailed Widowbird [Euplectes axillaris]; Pryke and Andersson 2003).

Investigators have suggested that in cooperative species, potential dispersers choose either to remain on a natal territory as a helper and "stay-and-foray" or depart from natal territories and search as a "floater" until they find a territory vacancy to fill (Brown 1987; Walters et al. 1992, 2004). Stay-and-foray models have been envisaged for cooperative breeders (Reed et al. 1999), and simulations have shown the relative benefits of such a "foray search" strategy over the random strategies (Boulinier and Danchin 1997, Conradt et al. 2003); many male Redcockaded Woodpeckers exemplify the pattern (Walters et al. 2004). None of the radiomarked Micronesian Kingfishers employed a floater dispersal strategy during 3,929 telemetry* ${ }^{*}$ ird $^{*}$ days. Instead, birds made movements that resembled a stay-and-foray strategy, because prospecting was directed, repeated, and short in duration and birds returned to their home territories before sunset. This may reflect attempts to retain social status and nepotistic benefits on a natal territory (Ekman et al. 2001, 2004; Dickinson and Hatchwell 2004) while simultaneously gathering contemporary information about extrinsic conditions with which to make informed decisions about the costs and benefits of dispersal.

Our results suggest that prospecting may provide an opportunity to solicit reproduction (e.g., Pitcher and Stutchbury 2000). Although parentage has not been investigated in Micronesian Kingfishers, previous studies of other cooperatively breeding species show high levels of promiscuity and extrapair paternity (Mulder et al. 1994, DeLay et al. 1996, Li and Brown 2000, Richardson et al. 2001; but see Haig et al. 1994). Prospecting movements of dominants were temporally aligned with courtship observations and nest initiations (Fig. 1), and we observed prospecting individuals meeting neighboring females at nest sites several days before laying. In contrast to previous descriptions of other species (Reed et al. 1999), some prospecting Micronesian Kingfishers were not failed breeders that were merely gathering information about resources, because they went on to breed with mates on home territories shortly thereafter.

Reproduction obtained during extraterritorial movements has the potential to greatly enhance the fitness of prospecting birds while simultaneously reducing that of cuckolded males. Additionally, costs to prospectors may be small, because we observed no mortality during extraterritorial movements. Covert reproduction by delayed dispersers during forays would provide evidence of a previously undocumented pathway to fitness, and suggests that delaying and foraying may be more of an alternative life-history strategy than simply "making the best of a bad situation," as some 
have suggested (e.g., Emlen 1997). Further, if covert extraterritorial helper reproduction is common in many species, the behavior even has the potential to alter perceptions about the costs and benefits of cooperative breeding and delayed dispersal, which have been debated for several decades (Skutch 1935, Brown et al. 1978, Vehrencamp 1980, Brown 1987, Stacey and Koenig 1990, Gerlach and Bartmann 2002, Haydock and Koenig 2003, Griffin et al. 2003). A molecular genetic investigation of parentage in Micronesian Kingfishers has the potential to lend insight into this phenomenon.

Dispersal. - Although rare, long-distance dispersal has been observed in other cooperatively breeding species (Bowen et al. 1989, Koenig et al. 1996). During our study, Micronesian Kingfishers neither prospected nor dispersed great distances from home territories. The island of Pohnpei is limited in size $(\sim 20 \mathrm{~km}$ in diameter), so dispersal distances may be restricted by behavior and geography.

An increased probability of obtaining a highquality breeding territory by delaying dispersal is fundamental to the benefits-of-philopatry hypothesis (Stacey and Ligon 1991). By delaying, individuals can inherit natal areas or occupy neighboring territories when vacancies occur. Thus, inheritance is characteristic of many cooperatively breeding species (Hale et al. 2003), and some investigators have even suggested that long-term data sets might yield evidence of dynasties (Emlen 1997). To the contrary, our fiveyear investigation of Micronesian Kingfishers provides no evidence of helpers obtaining breeding vacancies through inheritance, because none of the delayed dispersers bred on natal territories. However, some helpers dispersed to neighboring territories, where they bred in subsequent years, so individuals may be queuing for breeding vacancies in nearby areas (Zack 1990).

In summary, the Micronesian Kingfisher is a highly territorial species that maintains allpurpose, year-round territories as pairs and cooperative groups. No Micronesian Kingfishers became floaters during our investigation, but all age and sex classes made short-duration prospecting movements to neighboring territories. Because juveniles and helpers made repeated and extended homesteading movements to settlement areas before dispersal, prospecting may allow birds to gather information about localized resources and conspecifics before making dispersal decisions. Prospecting movements of dominant birds were temporally associated with courtship and nesting activities, and birds were observed in proximity to oppositesex neighbors, which suggests that prospecting may also be used to solicit reproduction.

Results from this investigation suggest that a reintroduced population of Micronesian Kingfishers on Guam would require at least enough space for birds to maintain territories $\sim 8.1$ ha in size. The limited prospecting and dispersal distances detected here also suggest that a recovering population of Guam Kingfishers should not be expected to disperse across the landscape quickly. Additional investigation into parentage, and the interaction between specific resources, dispersal decisions, and population demography, would lend further insight into the costs and benefits of cooperative breeding in Micronesian Kingfishers.

\section{Acknowledgments}

We are indebted to all who have provided financial and technical support to this project. The U.S. Geological Survey Forest and Rangeland Ecosystem Science Center, U.S. Fish and Wildlife Service, Conservation Endowment Fund of the American Zoo and Aquarium Association, National Geographic Society, Disney's Animal Kingdom, St. Louis Zoo Field Research for Conservation Fund, Brookfield Zoo, Friends of the National Zoo, the Micronesian Kingfisher Species Survival Fund, and the Milwaukee County Zoo have provided financial backing for the project. B. Dugger, L. Houck, L. Kesler, I. Lopes, O. Taft, and J. Walters provided valuable comments on study design and manuscript development. D. Buden and B. Raynor provided advice on Pohnpei. We also extend thanks to the government of the Federated States of Micronesia, H. Anson, R. Mauricio, the landowners in Pohnpei, and everyone in the Haig Lab. M. Boris, C. Cantero, J. Santos, and P. Sanzenbacher also made contributions as field assistants and cultural guides. For information on LOAS software, see www.ecostats.com.

\section{Literature Cited}

Bahner, B., A. Baltz, and E. Diebold, Eds. 1998. Micronesian Kingfisher Species Survival 
Plan: Husbandry Manual. Zoological Society of Philadelphia, Pennsylvania.

Bensch, S., D. Hasselquist, B. Nielsen, and B. Hansson. 1998. Higher fitness for philopatric than for immigrant males in a semiisolated population of Great Reed Warblers. Evolution 52:877-883.

Bollmann, K., H-U. Reyer, and P. A. Brodmann. 1997. Territory quality and reproductive success: Can Water Pipits Anthus spinoletta assess the relationship reliably? Ardea 85:83-98.

Boulinier, T., And E. Danchin. 1997. The use of conspecific reproductive success for breeding patch selection in terrestrial migratory species. Evolutionary Ecology 11:505-517.

Bowen, B.S., R. R. Koford, and S. L. Vehrencamp. 1989. Dispersal in the communally breeding Groove-billed Ani (Crotophaga sulcirostris). Condor 91:52-64.

Breininger, D. R., AND D. M. Oddy. 2004. Do habitat potential, population density, and fires influence scrub-jay source-sink dynamics? Ecological Applications 14:1079-1089.

Brooker, M., And I. Rowley. 1995. The significance of territory size and quality in the mating strategy of the Splendid Fairy-wren. Journal of Animal Ecology 64:614-627.

Brown, J. L. 1964. The evolution of diversity in avian territorial systems. Wilson Bulletin 76: 160-169.

Brown, J. L. 1974. Alternate routes to sociality in jays - With a theory for the evolution of altruism and communal breeding. American Zoologist 14:63-80.

Brown, J. L. 1987. Helping and Communal Breeding in Birds: Ecology and Evolution. Princeton University Press, Princeton, New Jersey.

Brown, J. L., D. D. Dow, E. R. Brown, and S. D. Brown. 1978. Effects of helpers on feeding of nestlings in the Grey-Crowned Babbler (Pomatostomus temporalis). Behavioral Ecology and Sociobiology 4:43-59.

Buden, D. W. 2000. A comparison of 1983 and 1994 bird surveys of Pohnpei, Federated States of Micronesia. Wilson Bulletin 112: 403-410.

Byrkjedal, I., G. B. Grønstol, T. Lislevand, K. M. Pedersen, H. SandviK, And S. Stalheim. 1997. Mating systems and territory in Lapwings Vanellus vanellus. Ibis 139: 129-137.
Clark, R. G., and D. Shutler. 1999. Avian habitat selection: Pattern from process in nestsite use by ducks? Ecology 80:272-287.

Clobert, J., J. O. Wolff, J. D. Nichols, E. Danchin, and A. A. Dhondt. 2001. Introduction. Pages xvii-xxi in Dispersal ( $\mathrm{J}$. Clobert, E. Danchin, A. A. Dhondt, and J. D. Nichols, Eds.). Oxford University Press, Oxford, United Kingdom.

Conradt, L., P. A. Zollner, T. J. Roper, K. FrANK, AND C. D. Thomas. 2003. Foray search: An effective systematic dispersal strategy in fragmented landscapes. American Naturalist 161:905-915.

DeLay, L. S., J. Faaborg, J. Naranjo, S. M. Paz, T. deVries, And P. G. PArker. 1996. Paternal care in the cooperatively polyandrous Galapagos Hawk. Condor 98:300-311.

Dickinson, J. L., And B. J. Hatchwell. 2004. Fitness consequences of helping. Pages 4866 in Ecology and Evolution of Cooperative Breeding in Birds (W. D. Koenig and J. L. Dickinson, Eds.). Cambridge University Press, Cambridge, United Kingdom.

Doolan, S. P., AND D. W. Macdonald. 1996. Dispersal and extra-territorial prospecting by slender-tailed meerkats, Suricata suricatta, in the southwestern Kalahari. Journal of Zoology (London) 240:59-73.

EkMAN, J., V. Baglione, S. Eggers, AND M. Griesser. 2001. Delayed dispersal: Living under the reign of nepotistic parents. Auk 118:1-10.

Ekman, J., L. Dickinson, J. Hatchwell, and M. Griesser. 2004. Delayed dispersal. Pages 3547 in Ecology and Evolution of Cooperative Breeding in Birds (W. D. Koenig and J. L. Dickinson, Eds.). Cambridge University Press, Cambridge, United Kingdom.

Emlen, J. T., And L. W. Oring. 1977. Ecology, sexual selection, and the evolution of mating systems. Science 197:215-223.

EmLen, S. T. 1982. The evolution of helping. I. An ecological constraints model. American Naturalist 119:29-39

Emlen, S. T. 1997. Predicting family dynamics in social vertebrates. Pages 228-253 in Behavioural Ecology: An Evolutionary Approach, 4th ed. (J. R. Krebs and N. B. Davies, Eds.). Blackwell Science, Oxford, United Kingdom.

Engbring, J., F. L. Ramsey, and V. J. Wildman. 1990. Micronesian Forest Bird Surveys, the 
Federated States: Pohnpei, Kosrae, Chuuk, and Yap. U.S. Fish and Wildlife Service, Honolulu, Hawaii.

Fedy, B. C., And B. J. M. Stutchbury. 2004. Territory switching and floating in Whitebellied Antbird (Myrmeciza longipes), a resident tropical passerine in Panama. Auk 121: 486-496.

Forbes, S., R. Grosshans, and B. Glassey. 2002. Multiple incentives for parental optimism and brood reduction in blackbirds. Ecology 83:2529-2541.

FRY, C. H., AND K. Fry. 1992. Kingfishers, BeeEaters, and Rollers. Princeton University Press, Princeton, New Jersey.

Gaston, A. J. 1978. The evolution of group territorial behavior and cooperative breeding. American Naturalist 112:1091-1100.

Gerlach, G., AND S. Bartmann. 2002. Reproductive skew, costs, and benefits of cooperative breeding in female wood mice (Apodemus sylvaticus). Behavioral Ecology 13:408-418.

Greenwood, P. J. 1980. Mating systems, philopatry and dispersal in birds and mammals. Animal Behaviour 28:1140-1162.

Greenwood, P. J., And P. H. Harvey. 1982. The natal and breeding dispersal of birds. Annual Review of Ecology and Systematics 13:1-21.

Griffin, A. S., J. M. Pemberton, P. N. M. Brotherton, G. McIlrath, D. Gaynor, R. Kansky, J. O'Riain, and T. H. CluttonBRock. 2003. A genetic analysis of breeding success in the cooperative meerkat (Suricata suricatta). Behavioral Ecology 14:472-480.

Haig, S. M., And J. D. Ballou. 1995. Genetic diversity in two avian species formerly endemic to Guam. Auk 112:445-455.

Haig, S. M., J. D. Ballou, and N. J. Casna. 1995. Genetic identification of kin in Micronesian Kingfishers. Journal of Heredity 86:423-431.

Haig, S. M., J. R. Walters, and J. H. Plissner. 1994. Genetic evidence for monogamy in the cooperatively breeding Red-cockaded Woodpecker. Behavioral Ecology and Sociobiology 34:295-303.

Hale, A. M., D. A. Williams, and K. N. RABENOLD. 2003. Territoriality and neighbor assessment in Brown Jays (Cyanocorax morio) in Costa Rica. Auk 120:446-456.

Haydock, J., AND W. D. Koenig. 2002. Reproductive skew in the polygynandrous
Acorn Woodpecker. Proceedings of the National Academy of Sciences USA 99: 7178-7183.

Haydock, J., And W. D. Koenig. 2003. Patterns of reproductive skew in the polygynandrous Acorn Woodpecker. American Naturalist 162:277-289.

Hixon, M. A. 1980. Food production and competitor density as the determinants of feeding territory size. American Naturalist 115: 510-530.

Hooge, P. N., and B. Eichenlaub. 1997. Animal Movement Extension to ARCVIEW, version 1.1. Alaska Science Center, Biological Science Office, U.S. Geological Survey, Anchorage, Alaska.

Johnson, D. M., And C. C. Horvitz. 2005. Estimating postnatal dispersal: Tracking the unseen dispersers. Ecology 86:1185-1190.

Kesler, D. C. 2002. Nest site selection in cooperatively breeding Pohnpei Micronesian Kingfishers (Halcyon cinnamomina reichenbachii): Does nest-site abundance limit reproductive opportunities? M.S. thesis, Oregon State University, Corvallis.

Kesler, D. C., AND S. M. Haig. 2004. Thermal characteristics of wild and captive Micronesian Kingfisher nesting habitats. Zoo Biology 23:301-308.

Kesler, D. C., And S. M. Haig. 2005a. Microclimate and nest-site selection in Micronesian kingfishers. Pacific Science 59:499-508.

Kesler, D. C., And S. M. Haig. 2005b. Selection of arboreal termitaria for nesting by cooperatively breeding Micronesian Kingfishers Todiramphus cinnamominus reichenbachii. Ibis 147:188-196.

Koenig, W. D., P. N. Hooge, M. T. Stanback, AND J. HAyDock. 2000. Natal dispersal in the cooperatively breeding Acorn Woodpecker. Condor 102:492-502.

Koenig, W. D., and F. A. Pitelka. 1981. Ecological factors and kin selection in the evolution of cooperative breeding in birds. Pages 261-280 in Natural Selection and Social Behavior: Recent Research and New Theory (R. D. Alexander and D. W. Tinkle, Eds.). Chiron Press, New York.

Koenig, W. D., F. A. Pitelka, W. J. Carmen, R. L. Mumme, and M. T. Stanback. 1992. The evolution of delayed dispersal in cooperative breeders. Quarterly Review of Biology 67:111-150. 
Koenig, W. D., D. Van Vuren, and P. N. Hooge. 1996. Detectability, philopatry, and the distribution of dispersal distances in vertebrates. Trends in Ecology and Evolution 11:514-517.

Komdeur, J. 1991. Influence of territory quality and habitat saturation on dispersal options in the Seychelles Warbler: An experimental test of the habitat saturation hypothesis for cooperative breeding. Pages 1325-1332 in Acta XX Congressus Internationalis Ornithologici (B. D. Bell, Ed.). Congress Trust Board, Wellington, New Zealand.

Komdeur, J. 1992. Importance of habitat saturation and territory quality for evolution of cooperative breeding in Seychelles Warbler. Nature 358:493-494.

Komdeur, J. 1994. Experimental evidence for helping and hindering by previous offspring in the cooperative-breeding Seychelles Warbler Acrocephalus sechellensis. Behavioral Ecology and Sociobiology 34:175-186.

Langen, T. A., And S. L. Vehrencamp. 1998. Ecological factors affecting group and territory size in White-throated Magpie-Jays. Auk 115:327-339.

Li, S.-H., ANd J. L. Brown. 2000. High frequency of extrapair fertilization in a plural breeding bird, the Mexican Jay, revealed by DNA microsatellites. Animal Behaviour 60:867-877.

Ligon, J. D. 1999. The Evolution of Avian Breeding Systems. Oxford University Press, Oxford, United Kingdom.

Ligon, J. D., AND S. H. Ligon. 1990. Green Woodhoopoes: Life history traits and sociality. Pages 33-65 in Cooperative Breeding in Birds: Long-term Studies of Ecology and Behavior (P. B. Stacey and W. D. Koenig, Eds.). Cambridge University Press, Cambridge, United Kingdom.

LimA, S. L. 1984. Territoriality in variable environments: A simple model. American Naturalist 124:641-655.

LõHmus, A., AND Ü. VäLI. 2004. The effects of habitat quality and female size on the productivity of the Lesser Spotted Eagle Aquila pomarina in the light of the alternative prey hypothesis. Journal of Avian Biology 35: 455-464.

Luck, G. W. 2003. Differences in the reproductive success and survival of the Rufous Treecreeper (Climacteris rufa) between a fragmented and unfragmented landscape. Biological Conservation 109:1-14.
Mueller-Dombois, D., And F. R. Fosberg. 1998. Vegetation of the Tropical Pacific Islands. Springer, New York.

Mulder, R. A., P. O. Dunn, A. Cockburn, K. A. Lazenby-Cohen, and M. J. Howell. 1994. Helpers liberate female fairy-wrens from constraints on extra-pair mate choice. Proceedings of the Royal Society of London, Series B 255:223-229.

PÄrT, T. 1994. Male philopatry confers a mating advantage in the migratory Collared Flycatcher, Ficedula albicollis. Animal Behaviour 48:401-409.

Pasinelli, G., K. Schiegg, and J. R. Walters. 2004. Genetic and environmental influences on natal dispersal distance in a resident bird species. American Naturalist 164:660-669.

Pitcher, T. E., And B. J. M. Stutchbury. 2000. Extraterritorial forays and male parental care in Hooded Warblers. Animal Behaviour 59:1261-1269.

Porter, J. H., And J. L. Dooley, Jr. 1993. Animal dispersal patterns: A reassessment of simple mathematical models. Ecology 74: 2436-2443.

Pratt, H. D., P. L. Bruner, and D. G. Berrett. 1987. A Field Guide to the Birds of Hawaii and the Tropical Pacific. Princeton University Press, Princeton, New Jersey.

Pribil, S., ANd W. A. Searcy. 2001. Experimental confirmation of the polygyny threshold model for Red-winged Blackbirds. Proceedings of the Royal Society of London, Series B 268:1643-1646.

Pryke, S. R., ANd S. Andersson. 2003. Carotenoidbased epaulettes reveal male competitive ability: Experiments with resident and floater Red-shouldered Widowbirds. Animal Behaviour 66:217-224.

Rappole, J. H., And A. R. Tipton. 1991. New harness design for attachment of radio transmitters to small passerines. Journal of Field Ornithology 62:335-337.

Reed, J. M., T. Boulinier, E. Danchin, AND L. W. Oring. 1999. Informed dispersal: Prospecting by birds for breeding sites. Pages 189-259 in Current Ornithology, vol. 15 (V. Nolan, Jr., E. D. Ketterson, and C. F. Thompson, Eds.). Plenum Press, New York.

Richardson, D. S., F. L. Jury, K. BlaAkmeer, J. Komdeur, And T. Burke. 2001. Parentage assignment and extra-group paternity in a cooperative breeder: The Seychelles Warbler 
(Acrocephalus sechellensis). Molecular Ecology 10:2263-2273.

Roshier, D. A., AND J. R. W. Reid. 2003. On animal distributions in dynamic landscapes. Ecography 26:539-544.

SAvidge, J. A. 1987. Extinction of an island forest avifauna by an introduced snake. Ecology 68:660-668.

Schjørring, S., J. Gregersen, and T. Bregnballe. 1999. Prospecting enhances breeding success of first-time breeders in the Great Cormorant, Phalacrocorax carbo sinensis. Animal Behaviour 57:647-654.

Schoener, T. W. 1983. Simple models of optimal feeding-territory size: A reconciliation. American Naturalist 121:608-629.

Selander, R. K. 1964. Speciation in Wrens of the Genus Campylorhynchus. University of California Publications in Zoology 74: 1-305.

SкUтсн, A. F. 1935. Helpers at the nest. Auk 52: 257-273.

Smith, R. D., and N. B. Metcalfe. 1997. Where and when to feed: Sex and experience affect access to food in wintering Snow Buntings. Behaviour 134:143-160.

Stacey, P. B. 1979. Habitat saturation and communal breeding in the Acorn Woodpecker. Animal Behaviour 27:1153-1166.

Stacey, P. B., and W. D. Koenig, Eds. 1990. Cooperative Breeding in Birds: LongTerm Studies of Ecology and Behavior. Cambridge University Press, Cambridge, United Kingdom.

Stacey, P. S., and J. D. Ligon. 1991. The benefitsof-philopatry hypothesis for the evolution of cooperative breeding: Variation in territory quality and group size effects. American Naturalist 137:831-846.

Stamps, J. A., and V. V. Krishnan. 1999. A learning-based model of territory establishment. Quarterly Review of Biology 74:291-318.

Tyre, A. J., H. P. Possingham, and D. B. LindenMAYER. 2001. Inferring process from pattern: Can territory occupancy provide information about life history parameters? Ecological Applications 11:1722-1737.

U.S. Fish and Wildlife Service. 1984. Endangered and threatened wildlife and plants: Determination of endangered status for seven birds and two bats on Guam and the Northern Mariana Islands. Federal Register 50 CFR Part 17 49:33881-33885.

U.S. Fish and Wildlife Service. 2004. Draft Revised Recovery Plan for the Sihek or Guam Micronesian Kingfisher (Halcyon cinnamomina cinnamomina). U.S. Fish and Wildlife Service, Portland, Oregon. [Online.] Available at www.epa.gov/fedrgstr/EPASPECIES/2004/April/Day-28/e9585.htm.

Vehrencamp, S. L. 1980. To skew or not to skew? Pages 869-874 in Acta XVII Congressus Internationalis Ornithologici (R. Nöhring, Ed.). Deutsche Ornithologen-Gesellschaft, Berlin.

Walters, J. R. 2000. Dispersal behavior: An ornithological frontier. Condor 102:479-481.

Walters, J. R., C. B. Cooper, S. J. Daniels, G. Pasinelli, And K. Schiegg. 2004. Conservation biology. Pages 197-227 in Ecology and Evolution of Cooperative Breeding in Birds (W. D. Koenig and J. L. Dickinson, Eds.). Cambridge University Press, Cambridge, United Kingdom.

Walters, J. R., C. K. Copeyon, and J. H. Carter III. 1992. Test of the ecological basis of cooperative breeding in Red-cockaded Woodpeckers. Auk 109:90-97.

White, G. C., and R. A. Garrott. 1990. Analysis of Wildlife Radio-tracking Data. Academic Press, San Diego, California.

ZACK, S. W. 1990. Coupling delayed breeding with short-distance dispersal in cooperatively breeding birds. Ethology 86:265-289.

Zwicker, S. M., AND J. R. WALters. 1999. Selection of pines for foraging by Redcockaded Woodpeckers. Journal of Wildlife Management 63:843-852.

Associate Editor: M. Brittingham 